\title{
Корекція десикації очеревини, зумовленої карбоксиперитонеумом та гострою тонкокишковою непрохідністю в експерименті
}

\author{
Б. I. Слонецький ${ }^{1}$, М. І. Тутченко ${ }^{2}$, В. В. Вербицький ${ }^{1}$
}

${ }^{1}$ Національна медична академія післядипломної освіти імені П. Л. Шупика, м. Київ, ${ }^{2}$ Національний медичний університет імені О. О. Богомольця, м. Київ

\section{Correction of peritoneal desiccation, caused by carboxyperitoneum and an acute small-intestinal ileus in experiment}

\author{
B. I. Slonetskyi ${ }^{1}$, M. I. Tutchenko ${ }^{2}$, I. V. Verbitskyi ${ }^{1}$ \\ ${ }^{1}$ Shupyk National Medical Academy of Postgraduate Education, Kyiv, \\ ${ }^{2}$ Bogomolets National Medical University, Kyiv
}

\begin{abstract}
Реферат
Мета. Дослідити окремі особливості стану парієтальної очеревини під впливом напруженого карбоксиперитонеуму у тварин з 12-годинною гострою тонкокишковою непрохідністю (ГТКН).

Матеріали і методи. Проаналізовані результати дослідження стану парієтальної очеревини у 36 білих щурів-самців в умовах напруженого карбоксиперитонеуму. У тварин 1-ї групи застосовували карбоксиперитонеум, створюючи внутрішньочеревний тиск $9-10$ мм рт. ст., протягом 2 год з фракційною його зміною через 20 хв протягом 10 с. У тварин 2-ї групи, на відміну від 1-ї, дослідження проводили в умовах 12-годинної ГТКН. Тваринам 3-ї групи, на відміну від 2-ї, попередньо вводили чотирикомпонентну дисперсну суміш з експозицією 15 хв.

Результати. Через добу після застосування напруженого карбоксиперитонеуму у піддослідних тварин спостерігали зменшення товщини парієтальної очеревини до $(25,76 \pm 2,32)$ мкм, середнього діаметра ядер мезотеліоцитів до (5,46 $\pm 0,48)$ мкм та чисельної щільності мезотеліоцитів до $(12,96 \pm 1,09)$ на 1 мм² $^{2}$ що поєднувалось зі зростанням концентрації різнофазних токсичних продуктів ліпопероксидації та проявами антиоксидантної ферментопатії. Дані процеси суттєво поглиблювались в умовах 12-годинної ГТКН. Застосування чотирикомпонентної дисперсної суміші суттєво ослаблювало агресивні наслідки внутрішньочеревних чинників та сприяло зростанню компенсаторних властивостей парієтальної очеревини.

Висновки

Використання двогодинного напруженого карбоксиперитонеуму призводить до десикації парієтальної очеревини у піддослідних тварин та підвищує в ній концентрацію токсичних продуктів ліпопероксидації і знижує концентрацію супероксиддисмутази та каталази, що вірогідно погіршується в умовах 12-годинної ГТКН. Внутрішньочеревне введення чотирикомпонентної дисперсної суміші вірогідно підвищує протекторні властивості парієтальної очеревини в умовах 12-годинної ГТКН.

ключові слова: карбоксиперитонеум; експеримент; кишкова непрохідність; парієтальна очеревина.

Abstract

Objective. To investigate the separate peculiarities of the parietal peritoneum state under impact of the tension carboxyperitoneum in animals with a 12-hour acute small-bowel ileus (ASBI).

Materials and methods. Results of the investigation of the parietal peritoneum state in 36 white male rats in conditions of the tension carboxyperitoneum were analyzed. In patients of the Group I carboxyperitoneum was applied, creating intraabdominal pressure $9-10 \mathrm{Hg} \mathrm{mm}$, during $2 \mathrm{~h}$ with its fractional change in $20 \mathrm{~min}$ during $10 \mathrm{sec}$. In laboratory animals of Group II, differing from the Group I, the investigations were conducted in conditions of 12-hour ASBI. To laboratory animals of Group III, differing from those of the Group II, beforehand a four-component disperse mixture with a 15 min exposition was introduced Results. In a day after application of the tension carboxyperitoneum in laboratory animals the reduction of the parietal peritoneum thickness have occurred to $(25.76 \pm 2.32) \mathrm{mcm}$, average diameter of the mesotheliocytes nuclei - to $(5.46 \pm 0.48) \mathrm{mcm}$ and quantitative density of mesotheliocytes - to (12.96 \pm 1.09$)$ by $1 \mathrm{~mm}^{2}$, what have accompanied with concentration of different-phasic toxic products of lipoperoxidase and signs of the antioxidant enzymopathy were observed. This processes were essentially deepened in conditions of a 12-hour ASBI. Application of a four-component disperse mixture essentially weakened aggressive consequences of intraabdominal causes and promoted raising of compensatory properties of parietal peritoneum. Conclusion. Application of a two-year stressed carboxyperitoneum leads to desiccation of parietal peritoneum in experimental animals and raises in it a concentration of toxic products of lipoperoxidase and lowers concentration of superoxidysmutase and catalase, what trustworthily worsens in conditions of a 12-hour ASBI. Intraabdominal injection of a four-component disperse mixture trustworthily raises protective properties of parietal peritoneum in conditions of a 12-hour ASBI.

Keywords: carboxyperitoneum; experiment; ileus; parietal peritoneum.
\end{abstract}

Протягом останніх десятиліть лапароскопічні технології почали широко застосовувати, окрім планової, і в невідкладній хірургії органів черевної порожнини $[1,2]$. Попри загальні оптимістичні тенденції щодо зміни тех- нологічного забезпечення невідкладного втручання, тривалі лапароскопічні операції із застосуванням напруженого карбоксиперитонеуму нерідко супроводжуються окремими регіонарними і системними негативними наслідка- 
ми, пов'язаними зі специфічною дією карбоксиперитонеуму на очеревину. Аналіз літературних джерел [3, 4] свідчить, що пошук різноманітних способів перитонеопротекції триває, проте проблема резистентності очеревини та профілактики агресивного злукоутворення в черевній порожнині поки що далека від остаточного вирішення.

Мета дослідження: вивчити окремі особливості стану парієтальної очеревини під впливом напруженого карбоксиперитонеуму у тварин з $12-$ годинною гострою тонкокишковою непрохідністю (ГТКН).

\section{Матеріали і методи дослідження}

Експериментальні дослідження проведені на 36 білих щурах-самцях масою тіла 250 - 290 г, яких утримували у віварії Національної медичної академії післядипломної освіти імені П. Л. Шупика в клітках $з$ контролем кімнатної температури, природною зміною темряви та світла, застосовуючи стандартний харчовий раціон, з дотриманням вимог асептики й антисептики та нормативних документів, що регламентують проведення експериментальних досліджень на лабораторних тваринах (Правила проведення робіт із використанням експериментальних тварин. Страсбург, 1997; Європейська конвенція про захист хребетних тварин, що використовуються для дослідних та інших наукових цілей. - Страсбург, 18.03.1986 р.; Директива Ради 86/609 ЕЕС про дотримання законів, постанов та адміністративних положень держав - членів з питань захисту тварин, що використовуються для експериментальної та іншої наукової мети, від 24.11.1986 р.; Загальні етичні правила експериментів на тваринах, ухвалені Першим національним конгресом з біоетики. - Київ, 2001).

Методом випадкової вибірки тварин розподілили на три групи по 12 в кожній групі. У тварин 1-ї групи застосовували карбоксиперитонеум, створюючи внутрішньочеревний тиск 9 - 10 мм рт. ст., протягом 2 год з фракційною його зміною через 20 хв протягом 10 с. У тварин 2-ї групи з моделлю 12-годинної ГТКН також застосовували карбоксиперитонеум, створюючи внутрішньочеревний тиск 9 - 10 мм рт. ст., протягом 2 год 3 фракційною його зміною через 20 хв протягом 10 с. Тваринам 3-ї групи, на відміну від 2-ї групи, в черевну порожнину попередньо вводили чотирикомпонентну суміш (карбоксиперитонеум, бупівакаїн, антибіотик, дефенсаль) з експозицією 15 хв.

ГТКН, ускладнену розлитим перитонітом, моделювали в такий спосіб. Піддослідній тварині виконували мінілапаротомію в проекції термінального відділу клубової кишки і накладали лігатурну петлю з оментопротекцією на тонку кишку, відступивши 3 - 4 см від ілеоцекального переходу. Лігатуру виводили підшкірно і через 7 діб, щоб зменшити наслідки хірургічної травми на перебіг патологічного процесу, моделювали ГТКН.

Зразки парієтальної очеревини забирали під час операції та через 24 год після неї.

Для оцінки особливостей реакції перекисного окиснення ліпідів (ПОЛ) і антиоксидантної системи взяті ділянки парієтальної очеревини обробляли охолодженим 0,9\% розчином натрію хлориду, далі проводили їх гомогенізацію в 0,05\% трис-НСl буфері $(\mathrm{pH}=7,8)$ та центрифугування за методом Н. Д. Сщенко [5]. В отриманому супернатанті досліджували концентрацію дієнових (ДК) та оксидієнових (ОК) кон'югатів, шифових основ (ШО), активність супероксиддисмутази (СОД), глутатіонпероксидази (ГПО), каталази та глутатіонредуктази (ГР) [6]. Морфометричні дослідження проводили згідно з рекомендаціями Г. Г Автанділова [7]. Отримані результати опрацьовували статистично з використанням t-критерію Стюдента і ступеня вірогідності (р) на персональному комп'ютері за допомогою програми Microsoft Excel 2013.

\section{Результати}

Деякі негативні тенденції клінічного застосування тривалого напруженого карбоксиперитонеуму в невідкладних умовах нерідко досить складно проаналізувати без експериментальних досліджень, за даними яких можливо систематизувати провокуючі чинники та окремі компенсаторні фактори. Саме тому ми досліджували стан реактивності парієтальної очеревини під впливом запального процесу та карбоксиперитонеуму.

За результатами експериментальних досліджень, отриманими у тварин 1-ї групи, встановлено, що двогодинний напружений карбоксиперитонеум призводить до морфологічних змін парієтальної очеревини (табл. 1). Через 24 год після операції спостерігали зменшення товщини парієтальної очеревини до $(25,76 \pm 2,32)$ мкм та середнього діаметра ядер мезотеліоцитів до $(5,46 \pm 0,48)$ мкм, а також чисельної щільності мезотеліоцитів до $(12,96 \pm 1,09)$ на 1 мм $^{2}$. Тобто тривалий напружений карбоксиперитонеум викликав десикацію парієтальної очеревини, яка зберігалася навіть через добу після припинення його застосування.

В умовах 12-годинної ГТКН також встановлено суттеві зміни стану парієтальної очеревини. Вірогідно збільшувалися середній діаметр ядер мезотеліоцитів до (8,69 \pm

\begin{tabular}{|c|c|c|c|c|c|}
\hline \multicolumn{6}{|l|}{ Таблиця 1.} \\
\hline \multirow{2}{*}{ Морфологічні ознаки } & \multirow{2}{*}{ Контроль } & \multirow{2}{*}{ 12-годинна ГТКН } & \multicolumn{3}{|c|}{ Групи тварин } \\
\hline & & & 1-ша & 2-га & 3-тя \\
\hline Товщина очеревини, мкм & $27,18 \pm 2,24$ & $44,32 \pm 3,89 *$ & $25,76 \pm 2,32 * \circ$ & $42,28 \pm 3,36^{* \circ}$ & $43,74 \pm 3,74^{* x}$ \\
\hline $\begin{array}{l}\text { Чисельна щільність } \\
\text { мезотеліоцитів, на } 1 \text { мм² }\end{array}$ & $13,72 \pm 1,06$ & $7,06 \pm 0,65^{*}$ & $12,96 \pm 1,09^{\circ}$ & $6,15 \pm 0,48^{* \circ}$ & $6,71 \pm 0,51 * x$ \\
\hline $\begin{array}{l}\text { Середній діаметр ядер } \\
\text { мезотеліоцитів, мкм }\end{array}$ & $6,07 \pm 0,53$ & $8,69 \pm 0,85^{*}$ & $5,46 \pm 0,48^{* \circ}$ & $7,64 \pm 0,52^{* \circ}$ & $8,39 \pm 0,74^{* x}$ \\
\hline $\begin{array}{ll}\text { Примітка. } & * \text { - вірогідні } \\
& \text { в умовах } 12 \\
& \text { Те саме у та }\end{array}$ & $\begin{array}{l}\text { них у порівня } \\
\text { ної ГТКН; }{ }^{\times}- \\
3 .\end{array}$ & $\begin{array}{l}\text { контролем; }{ }^{\circ}-\text { в } \\
\text { дність даних у п }\end{array}$ & $\begin{array}{l}\text { дність даних у г } \\
\text { Іянні з даними, }\end{array}$ & $\begin{array}{l}\text { чянні з даними, } \\
\text { маними у твару }\end{array}$ & $\begin{array}{l}\text { маними } \\
\text { групи. }\end{array}$ \\
\hline
\end{tabular}




\begin{tabular}{|c|c|c|c|c|c|}
\hline Таблиця 2. & $\begin{array}{l}\text { центрації r } \\
\text { есикації пі, }\end{array}$ & $\begin{array}{l}\text { тів ліпопероксv } \\
\text { карбоксиперит }\end{array}$ & $\begin{array}{l}\text { i (у. 0./мг ліпі } \\
\text { му }\end{array}$ & парієтальній & вині, \\
\hline \multirow{2}{*}{ Показники } & \multirow{2}{*}{ Контроль } & \multirow{2}{*}{ 12-годинна ГТКН } & \multicolumn{3}{|c|}{ Групи тварин } \\
\hline & & & 1-ша & 2-га & 3-тя \\
\hline ДК 233 & $0,57 \pm 0,05$ & $0,85 \pm 0,07^{*}$ & $0,65 \pm 0,05^{* \circ}$ & $1,02 \pm 0,11^{* \circ}$ & $0,78 \pm 0,06^{*^{x}}$ \\
\hline OK 278 & $0,42 \pm 0,04$ & $0,63 \pm 0,06^{*}$ & $0,51 \pm 0,07^{*}$ & $0,84 \pm 0,96^{* \circ}$ & $0,64 \pm 0,06^{*^{x}}$ \\
\hline ШО 400 & $1,08 \pm 0,09$ & $1,55 \pm 0,14^{*}$ & $1,22 \pm 0,16^{* \circ}$ & $1,82 \pm 0,12^{* \circ}$ & $1,62 \pm 0,15^{*^{x}}$ \\
\hline
\end{tabular}

\begin{tabular}{|c|c|c|c|c|c|}
\hline \multirow[t]{3}{*}{ Таблиця 3.} & \multirow{3}{*}{ Контроль } & \multirow{3}{*}{ 12-годинна ГТКН } & рментів у па & льній очерев & яка зазнала \\
\hline & & & \multicolumn{3}{|c|}{ Групи тварин } \\
\hline & & & 1-ша & 2-га & 3-тя \\
\hline ГПО, мкмоль/мг білка × с & $58,16 \pm 3,28$ & $42,52 \pm 2,46^{*}$ & $56,03 \pm 3,08^{* \circ}$ & $40,16 \pm 2,86^{* \circ}$ & $42,06 \pm 3,58^{*^{x}}$ \\
\hline ГР, мкмоль/мг білка × с & $36,02 \pm 2,08$ & $24,38 \pm 1,12^{*}$ & $34,54 \pm 3,11^{*}$ & $22,28 \pm 2,02^{* \circ}$ & $23,95 \pm 2,14^{*^{x}}$ \\
\hline СОД, нмоль/мг білка × с & $17,91 \pm 1,36$ & $12,44 \pm 1,09 *$ & $16,31 \pm 1,54^{* \circ}$ & $11,19 \pm 1,08^{* \circ}$ & $12,44 \pm 1,06^{* x}$ \\
\hline Каталаза, нмоль/мг білка × с & $9,28 \pm 0,76$ & $4,27 \pm 0,31^{*}$ & $8,78 \pm 0,69^{\circ}$ & $3,42 \pm 0,26^{* \circ}$ & $3,98 \pm 0,33^{* x}$ \\
\hline
\end{tabular}

0,85) мкм та товщина парієтальної очеревини до $(44,32 \pm$ $3,89)$ мкм, тоді як чисельна щільність мезотеліоцитів суттєво зменшувалась - до $(7,06 \pm 0,65)$ на 1 мм².

ГТКН викликала суттєве ослаблення протекторних властивостей парієтальної очеревини, що спостерігали у тварин 2-ї групи. Встановлено, що в умовах 12-годинної ГТКН та двогодинного напруженого карбоксиперитонеуму вірогідно зменшувалась чисельна щільність ме-

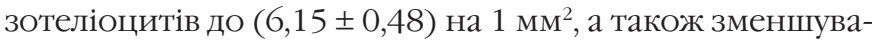
лися товщина очеревини до $(42,28 \pm 3,36)$ мкм і середній діаметр ядер мезотеліоцитів до $(7,64 \pm 0,52)$ мкм.

Застосування у тварин 3-ї групи чотирикомпонентної суміші вірогідно ослабило негативні наслідки газово-компресійних внутрішньочеревних рефлексів, що проявилося, на відміну від 2-ї групи, у зростанні протекторних властивостей парієтальної очеревини, товщина якої збільшилась до $(43,74 \pm 3,74)$ мкм, а чисельна щільність мезо-

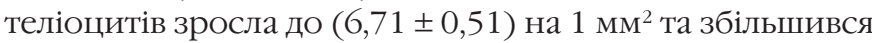
до $(8,39 \pm 0,74)$ мкм середній діаметр їх ядер.

Отримані результати стали підставою для вивчення функціональних змін парієтальної очеревини шляхом дослідження особливостей накопичення токсичних продуктів ПОЛ в умовах ентерогенного перитоніту та напруженого карбоксиперитонеуму.

Результати, отримані у тварин 1-ї групи, показали, що двогодинний напружений карбоксиперитонеум призводить до зростання концентрації різнофазних токсичних продуктів ліпопероксидації (табл. 2), зокрема, рівень ДК 233 збільшився до $(0,65 \pm 0,05)$, ОК 278 - до $(0,51 \pm 0,07)$ та ШО 400 - до $(1,22 \pm 0,16)$ у.О./мг ліпідів.

Перебіг 12-годинної ГТКН супроводжувався вірогідним збільшенням концентрації токсичних речовин у парієтальній очеревині. На відміну від 1-ї групи, у тварин 2-ї групи виявили суттєве збільшення концентрації ДК 233 до (1,02 $\pm 0,11)$, ОК 278 до $(0,84 \pm 0,96)$ та ШО 400 до $(1,82 \pm 0,12)$ у.о./мг ліпідів.

Результати, отримані у тварин 3-ї групи, дали підставу судити про парієтопротекторну дію чотирикомпонентної суміші, адже після ії застосування зменшувалась кон- центрація токсичних продуктів ліпопероксидації навіть в умовах ГТКН. Це підтверджено порівнянням результатів, отриманих у тварин 2-ї та 3-ї груп, та зменшенням концентрації як первинних та вторинних, так і кінцевих токсичних продуктів ПОЛ.

Крім дослідження концентрації продуктів ліпопероксидації в парієтальній очеревині в залежності від дії напруженого карбоксиперитонеуму та ГТКН, ми проаналізували окремі показники антиоксидантної системи. Результати, отримані у тварин 1-ї групи (табл.3), підтвердили антиоксидантну ферментопатію, що характеризувалася зменшенням активності ГПО до $(56,03 \pm 3,08)$ і ГР до $(34,54 \pm$ $3,11)$ мкмоль/мг білка × с, СОД до $(16,31 \pm 1,54)$, каталази до $(8,78 \pm 0,69)$ нмоль $/$ мг білка $\times$ с.

На відміну від тварин 1-ї групи, у тварин 2-ї групи десикація парієтальної очеревини суттєво поглиблювалась на тлі вираженого зменшення активності каталази, СОД та ГПО. Застосування чотирикомпонентної дисперсної суміші у тварин 3-ї групи покращувало антиоксидантний баланс парієтальної очеревини та характеризувалось збільшенням активності каталази до $(3,98 \pm 0,33)$ i СОД до $(12,44 \pm 1,06)$ нмоль/мг білка × с, ГПО до $(42,06 \pm$ $3,58)$ і ГР до $(23,95 \pm 2,14)$ мкмоль/мг білка $\times$ с.

\section{Обговорення}

Впровадження лапароскопічних операцій у невідкладну хірургію органів черевної порожнини на сучасному етапі безпосередньо пов'язане із застосуванням напруженого карбоксиперитонеуму, але в залежності від тривалості хірургічного втручання та індивідуальних особливостей пацієнта окремі автори спостерігали різноманітні ускладнення $[8,9]$.

Саме стан пацієнта, фаза та особливості перебігу захворювання пов'язані з компенсаторними резервами багатофункціональної очеревини, яка є однією з основних складових багатогранних регіонарних та системного процесів і може створювати передумови для виникнення в післяопераційному періоді злукової хвороби органів черевної порожнини [10, 11]. 
Проведені експериментальні дослідження виявили морфофункціональні зміни в парієтальній очеревині в залежності від різних агресивних факторів. Результати, отримані у тварин 1-ї групи, засвідчили, що у разі тривалого застосування напруженого карбоксиперитонеуму для парієтальної очеревини в залежності від ії компенсаторних резервів через 24 год після операції були характерні вірогідні морфологічні зміни, котрі у функціональному розрізі також проявлялися збільшенням концентрації різнофазних токсичних продуктів пероксидації та пригніченням антиоксидантних процесів.

Попередні дослідження [12] щодо стану вісцеральної очеревини в умовах моделювання патологічного процесу в черевній порожнині виявили чималу кількість реакцій, подібних до реакцій парієтальної очеревини, але 3 різноманітними відтінками, обумовленими морфофункціональними та структурними розбіжностями. Результати наведених експериментальних досліджень вказують на значне ослаблення протекторної функції очеревини у разі внутрішньочеревного поєднання компресійного та ентерогенних факторів. Це підтверджено шляхом оцінки стану парієтальної очеревини, зумовленого впливом напруженого карбоксиперитонеуму та ГТКН в експерименті на тваринах.

На сучасному етапі розвитку медичної галузі пошук різноманітних медикаментозних засобів, методів та компонентів хірургічного втручання триває $[13,14]$. Застосування у тварин 3-ї групи чотирикомпонентної суміші запобігало прогресуванню окремих негативних наслідків карбоксикомпресії та підвищувало компенсаторні резерви парієтальної очеревини, що сприяло оптимізації умов перебігу репаративних процесів у черевній порожнині, зменшувало агресивні наслідки хірургічного втручання та попереджало виникнення низки інтра - та екстраабдомінальних ускладнень.

\section{Висновки}

1. Використання двогодинного напруженого карбоксиперитонеуму призводить до десикації парієтальної очеревини у піддослідних тварин та підвищує в ній концентрацію токсичних продуктів ліпопероксидації і знижує активність СОД і каталази, що вірогідно погіршується в умовах 12-годинної ГТКН.

2. Внутрішньочеревне введення чотирикомпонентної дисперсної суміші вірогідно підвищує протекторні властивості парієтальної очеревини в умовах 12-годинної ГТКН.

\section{References}

1. Navez B, Navez J. Laparoscopy in the acute abdomen. Best Pract Res Clin Gastroenterol. 2014 Feb;28(1):3-17. doi: 10.1016/j.bpg.2013.11.006.

2. Tutchenko MI, Sloneckyi BI, Roschin GG, Zantaraia TM, Verbytskyi IV. Experience of urgent laparoscopy in patients with enhanced risk of operative intervention. Klin khir. 2018 Apr;(4):12-4. doi.org/10.26779/25221396.2018.04.12

3. Capobianco A, Cottone L, Monno A, Manfredi AA, Rovere-Querini P. The peritoneum: healing, immunity, and diseases. J Pathol. 2017 Oct;243(2):137-47. doi: 10.1002/path.4942.

4. Kowalewska PM, Patrick AL, Fox-Robichaud AE. Syndecan-1 in the mouse parietal peritoneum microcirculation in inflammation. PLoS One. 2014 Sep 3;9(9):e104537. doi: 10.1371/journal.pone.0104537.

5. Eshchenko ND. Videlenye i ochistka subkletochnikh i kletochnikh struktur. Metodiy biokhimicheskikh issledovaniy. Leningrad: Yzd-vo Leningrd un-t; 1982. S. 29-53. [In Russian].

6. Kamishnikov VS. Spravochnik po kliniko-biokhimicheskim issledovaniyam i laboratornoy diahnostyke Moskva: Medpress-inform; 2009. 896 c. [In Russian].

7. Avtandilov HH. Meditsinskaya morfometriya. Moskva: Medytsyna; 1990. $384 \mathrm{~s}$.

8. Quezada F, Quezada N, Mejia R, Brañes A, Padilla O, Jarufe N, et al. Laparoscopic versus open approach in the management of appendicitis complicated exclusively with peritonitis: a single center experience. Int J Surg. 2015 Jan;13:80-3.

doi: $10.1016 /$ j.ijsu.2014.11.027.

9. Wasnik AP, Maturen KE, Kaza RK, Al-Hawary MM, Francis IR. Primary and secondary disease of the peritoneum and mesentery: review of anatomy and imaging features. Abdom Imaging. 2015 Mar;40(3):62642. doi: 10.1007/s00261-014-0232-8.

10.Van Baal JO, Van de Vijver KK, Nieuwland R, van Noorden CJ, van Driel WJ, Sturk A, Kenter GG, et al. The histophysiology and pathophysiology of the peritoneum. Tissue Cell. 2017 Feb;49(1):95-105. doi: 10.1016/j.tice.2016.11.004.

11. Kouritas VK, Tepetes K, Spyridakis M, Theodosopoulou KV, Gourgoulianis KI, Molyvdas PA, et al. Role of histamine in altering fluid recycling in normal and post-traumatic rabbit peritoneum. Inflammation. 2014 Apr;37(2):534-41. doi: 10.1007/s10753-013-9767-z.

12. Slonetsky B, Dovzhenko O, Verbitskiy I, Maksimenko M, Kocubenko V. Prevention of peritoneal desiccation in acute adhesive intestinal obstruction. Georgian Medical News.

2014;(7-8)103-6. [In Russian].

13. Salakhov EK, Vlasov AP, Bolotskyh VA. Prognostic criteria of efficacy of programmed laparoscopic sanitation of the abdominal cavity in peritonitis. Khirurgiya. Zhurnal imeni N.I. Pirogova. 2017;(10):57-60. doi: 10.17116/hirurgia20171057-60. [In Russian].

14. Larichev AB, Pokrovskiı̌ EZ. Laparoscopic techniques in stage abdominal sanation for common pyoperitonitis. Khirurgiya. Zhurnal imeni N.I. Pirogova. 2015;(2):44-9. doi: 10.17116/hirurgia2015244-49. [In Russian]. 